\title{
Addressing current knowledge gaps on radionuclide transfer to reptiles
}

\author{
M.D. Wood ${ }^{1}$, N.A. Beresford ${ }^{2}$, T.L. Yankovich ${ }^{3}$, \\ D.V. Semenov ${ }^{4}$ and D. Copplestone ${ }^{5}$ \\ ${ }^{1}$ School of Science \& the Environment, Manchester Metropolitan University, \\ Manchester, M1 5GD, UK \\ ${ }^{2}$ Centre for Ecology \& Hydrology, Bailrigg, Lancaster, LA1 4AP, UK \\ ${ }^{3}$ Saskatchewan Research Council, Saskatoon, SK, S7N 2X8, Canada \\ ${ }^{4}$ A.N. Severtsov Institute of Ecology \& Evolution, Russian Academy of Sciences, \\ 119071 Moscow, Russia \\ ${ }^{5}$ School of Biological \& Environmental Sciences, University of Stirling, Stirling, FK9 4LA, UK
}

\begin{abstract}
Model intercomparison exercises have identified radionuclide transfer predictions as the greatest source of uncertainty in biota dose assessments. One wildlife group for which few transfer data exist is reptiles, Given that reptiles are an important, and often protected, component of many ecosystems and that assessments of radiation impact on ecosystems are becoming increasingly necessary due to the current nuclear renaissance, there is a need to further develop our current database on transfer to reptiles or find alternative approaches to estimate reptile transfer parameters. Three approaches that have the potential to increase the availability of parameters to predict radionuclide transfer to reptiles are the use of nonlethal sampling techniques, phylogenetic relationships and allometric relationships. Non-lethal sampling is an attractive long term option for deriving transfer parameters, but the derivation of phylogenetic and allometric relationships could provide ways of predicting transfer in the interim.
\end{abstract}

\section{INTRODUCTION}

Model intercomparison exercises have identified radionuclide transfer predictions as the greatest source of uncertainty in biota dose assessments [1, 2]. In response to this an International Atomic Energy Agency (IAEA) Working Group was established to develop an international database of transfer parameters for wildlife [3]. One wildlife group for which few transfer data exist is reptiles (Class Reptilia). Within this highly diverse Class, the main reptile groups that may need to be considered when conducting biota dose assessments are snakes (Order: Squamata, Suborder: Serpentes), lizards (Order: Squamata, Suborder: Sauria), crocodilians (Order: Crocodylia) and turtles, terrapins and tortoises (Order: Testudinata) [4].

The parameter used most commonly to predict radionuclide transfer is the $\mathrm{CR}_{\text {wo-media }}$, which is the equilibrium ratio between the radionuclide activity concentration in the whole organism (fresh weight) and that in media (soil (dry weight), water or air) [3]. A comprehensive review of published and unpublished international data sets on transfer to reptiles provided $\mathrm{CR}_{\text {wo-media }}$ data for 35 elements (Am, As, B, Ba, Ca, Cd, Ce, Cm, Co, Cr, Cs, Cu, Fe, Hg, K, La, Mg, Mn, Mo, Na, Ni, Pb, Po, Pu, Ra, $\mathrm{Rb}, \mathrm{Sb}, \mathrm{Se}, \mathrm{Sr}, \mathrm{Th}, \mathrm{U}, \mathrm{V}, \mathrm{Y}, \mathrm{Zn}, \mathrm{Zr}$ ) to reptiles in freshwater ecosystems and 15 elements (Am, C, Cs, $\mathrm{Cu}, \mathrm{K}, \mathrm{Mn}, \mathrm{Ni}, \mathrm{Pb}, \mathrm{Po}, \mathrm{Pu}, \mathrm{Sr}, \mathrm{Tc}, \mathrm{Th}, \mathrm{U}, \mathrm{Zn}$ ) to reptiles in terrestrial ecosystems [4]. However, many of these $\mathrm{CR}_{\mathrm{wo} \text {-media }}$ data were derived from a single study or data value and there were no data for marine reptiles. Given that reptiles are an important, and often protected, component of many ecosystems [5] and that assessments of radiation impact on ecosystems are becoming increasingly necessary due to the current nuclear renaissance, there is a need to further develop our current database on transfer to reptiles. 
The traditional radioecological approach would be to undertake targeted field research in which reptiles and environmental media are sampled destructively and analysed using standard radiometric techniques (e.g. [5]). However, this is a resource intensive solution and the protected nature of reptiles and the ethics surrounding destructive sampling make it desirable to consider alternatives to the standard destructive sampling approaches. Three approaches that may be used to fill some of the knowledge gaps are: (i) using analysis of non-lethally harvested tissues (e.g. osteoderms, tail tissue, eggs, blood and skin) for estimating whole organism contaminant burdens; (ii) analysis of evolutionary history (phylogenetic) relationships in radionuclide transfer; and (iii) biological scaling relationships (allometry).

This paper evaluates these three potential approaches for addressing current gaps in reptile transfer database and considers the extent to which the currently available data sets can support the implementation of these approaches.

\section{APPROACHES TO FILLING CURRENT KNOWLEDGE GAPS}

\subsection{Non-lethal sampling techniques}

There is a growing demand for the development and refinement of non-lethal sampling strategies to determine contaminant burdens in reptiles [6]. Live monitoring for gamma emitters has been used in some studies at radionuclide contaminated sites (e.g. [7]). However, given the low activity concentrations in reptiles at many study locations, this technique is unlikely to be practical in most research situations due to the long count times that would be required. Therefore, direct analysis of tissue samples is necessary and several studies over the past decade have evaluated the effectiveness of using various tissues, harvested using non-lethal techniques, for estimating contaminant burdens in reptiles. Tissues considered include osteoderms, scutes, skin, tail tissue, eggs and blood.

\subsubsection{Osteoderms, scutes and skin}

Osteoderms and scutes are two structures associated with reptilian skin. Scute is a term used to describe the keratinised tissue that forms into plates on the outer surface of turtle shells and on the skin of crocodiles. Bony deposits may develop beneath theses plates and are referred to as osteoderms [8].

Osteoderms are found in turtles, crocodilians and some lizards, but not in snakes [8]. Sampling of these dermal bones in crocodilians has been successfully demonstrated as a non-lethal technique for estimating concentrations of $\mathrm{Ca}, \mathrm{Co}, \mathrm{Pb}, \mathrm{Mg}$ and $\mathrm{U}$ in crocodiles (e.g. [9, 10]), although it may be necessary to correct for age and snout-vent length [11]. However, the harvesting of osteoderms in lizards would not be practical because they are microscopic and deeply embedded within the dermis. The procedure would also be unsuitable for turtles.

Turtle scutes have been shown to correlate with metal contamination in body tissues [12], but the significance of these correlations may be species-specific [13]. Also, because the turtle scute is a keratin plate formed from annual laminations, there is a disconnect between the content of the scute and current metabolic activity [14]. However, analytical techniques such as Laser Ablation Inductively Coupled Plasma Mass Spectrometry (LA ICP-MS) provide one way in which the contaminant concentrations in different scute laminations can be analysed. This technique enables uptake chronologies to be calculated [15], which could lead to more accurate prediction of both contemporary and historical body burdens in turtles.

Analysis of contaminant residues in skin samples, which can be biopsied in the field under local anaesthetic, has also been investigated as a non-lethal technique for monitoring contaminant burdens in reptiles (e.g. [16, 17]) and for determining internal tissue concentrations (e.g. [18]). Skin shedding, or sloughing, happens on a regular basis in snakes and there is evidence to suggest that this may provide a route for reducing contaminant burdens $[19,20]$. However, excretion of sequestered contaminants via the skin may not be as prevalent in other reptile groups. For example, laboratory-based research 
on Cd uptake in Podarcis carbonelli (Carbonell's wall lizard) demonstrated minimal loss of the Cd body-burden via skin shedding [21]. Skin samples may thus show promise as a non-lethal technique but relationships between skin and internal tissue concentrations for different elements and reptile groups would need to be well-defined.

\subsubsection{Tail tissue}

Work on Alligator mississippiensis (American alligator) has demonstrated that tail-tip samples (consisting of the distal $2 \mathrm{~cm}$ of the tail) are relatively easy to collect in the field and can be used to estimate the internal tissue concentrations, and hence whole-body burdens, of $\mathrm{As}, \mathrm{Cr}$ and $\mathrm{Cd}$ [22]. However, tail-tip sampling does not appear to have been used more widely in reptile contaminant burden analysis undertaken to date. Burger et al. [22] suggest that tail-tip tissue can be collected without harming the animal. However, the animals in their study were euthanized at the time of collection to allow analysis of internal body tissues in addition to the tail tips. Further work would be required to establish whether tail-tip harvesting can truly be regarded as a minimally invasive non-lethal sampling technique for alligators and to assess the extent to which the technique may be applicable to other reptile groups.

\subsubsection{Eggs}

In oviparous species, egg laying is a recognised route through which contaminants may be excreted by females [23-25]. Therefore, some studies have considered the extent to which egg contaminant burdens may be used to predict tissue and whole-body contaminant burdens in the female which laid the egg (e.g. $[26,27]$ and these have provided positive support for the use of this non-lethal sampling strategy. For example, analysis of stable element concentrations in the tissues and eggs of female sea turtles has demonstrated that concentrations in sea turtle eggs can be used to estimate concentrations in adult female turtles for elements such as $\mathrm{Cd}$ and $\mathrm{Zn}$ [28]. Some eggs are infertile and fail to develop so these can be collected from nests as a non-lethal approach for determining element concentrations in adult reptile tissues. Analysing eggs, especially infertile eggs, is less damaging to the species than sampling body tissues [24] and this non-lethal technique is gaining general acceptance within the scientific community [29].

\subsubsection{Blood}

The relationships between element concentrations in reptile blood relative to concentrations in other tissues have been investigated by a number of authors (e.g. [12, 16, 18]). Positive correlations have been identified for particular blood, tissue and element combinations, such as mercury concentrations in blood and muscle of Nerodia sipedon (Northern water snakes) [18], and blood sampling may therefore provide an alternative route to investigating element concentrations in adult reptiles. Although blood has been used exclusively by some authors for evaluating contaminant uptake in reptiles [30], blood generally reflects recent contaminant exposure [18] and the complex kinetics of elements within blood [27] are likely to result in high uncertainties.

There is also evidence to suggest that the physiological control of element levels in plasma may be different within across the reptile groups and also between species within the same group. For example, the activity of many enzymes in snake venom is dependent on the presence of various inorganic elements [31]. The haemorrhagic effectiveness of metalloproteases in venom from Crotalus spp (rattlesnake species) is dependent on the presence of $\mathrm{Zn} \mathrm{[32]} \mathrm{and} \mathrm{the} \mathrm{structural} \mathrm{integrity} \mathrm{of} \mathrm{haemorrhagic} \mathrm{and}$ proteolytic enzymes and anti-coagulants in the venom of the Agkistrodon acutus (sharp-nosed viper) is maintained by $\mathrm{Ca}$ ions [33]. Although the extent of and mechanisms for concentration of these inorganic elements into snake venom may not be fully understood [34, 35], this may indicate that snakes 
have an increased dietary uptake efficiency for particular elements and/or physiological mechanisms for increasing $\mathrm{Zn}$ concentrations in the venom glands. This is consistent with reptile haematology data which indicate that snakes have elevated blood concentrations of specific elements, such as $\mathrm{Zn}$ [36], compared to other reptiles. Therefore, estimating whole-body concentrations based on blood concentrations alone may require species-specific knowledge of the behaviour of certain elements.

An additional difficulty with using blood to estimate whole-body contaminant burdens is that, at least in the case of $N$. sipedon studied by Burger et al. [18], the blood sample ideally needs to be collected directly from the heart (cardiocentesis), which requires considerable expertise to achieve successful sample collection without injuring the snake. Whilst it is possible to sample blood from the caudal vein [6], and this may reduce the risk of serious injury to the snake, the volume of sample that can be collected from this vein may be insufficient for performing a suite of haematological analyses [18]. Jugular venipuncture provides an alternative option for non-lethal sample collection [37]. However, although available evidence indicates little difference in the blood chemistry of the different venipuncture sites [37], jugular puncture does not appear to have been used in studies of contaminant uptake to date.

\subsubsection{Do non-lethal techniques provide an immediate solution?}

Overall, there is strong evidence to support the use of non-lethal techniques in future monitoring of contaminant burdens in reptile populations, with both skin and infertile egg sampling appearing to be particularly effective. These techniques may provide a useful means for furthering understanding of transfer to reptiles and enable $\mathrm{CR}_{\text {wo-media }}$ values to be derived for many species with minimal impact (stress) to individual organisms and virtually no population impact. However, to fully utilise these techniques, there is a need to further develop the knowledge-base on the significance of the relationships, across a wider range of species, ecosystems and elements, between tissues that may be sampled nonlethally and whole-body contaminant burdens. One of the constraining factors may be the "correlational chaos" that has been observed between various tissues when contaminant concentrations are low [38]. Although there may be analytical and research challenges to be overcome, these non-lethal strategies remain a promising route to furthering understanding of contaminant transfer and exposure for protected species of reptile.

\subsection{Phylogenetic relationships}

The non-lethal sampling techniques described above could enable the reptile transfer database to be further developed with new empirical data and are likely to enable the accurate estimation of transfer to a broad range of reptile species, but further research and development is required to develop this field of work. In the interim, many gaps in our knowledge of transfer to reptiles remain and there is a need to investigate alternative methods to improve the accuracy of transfer predictions for reptiles in the dose assessments being undertaken at present. Phylogenetic relationships (the degree of relationship between species based on their evolutionary history), and the allometric (biological scaling) relationships discussed in Section 2.3, may provide scientifically justifiable approaches to estimating radionuclide transfer where data are lacking currently [39].

Recent studies have identified phylogenetic relationships in the transfer of radionuclides to plants and animals. For example, Jeffree et al. [40] have demonstrated that radionuclide uptake differs between chondrychthian and teleost fish species in the marine environment and that the differences reflect phylogenetic relationships. Willey [39] has made similar observations for plant species. It is reasonable to assume that studies of other organism groups would also reveal phylogenetic relationships. However, given the limited transfer database currently available for reptiles, the data are likely to be insufficient to enable phylogenetic analysis based on $\mathrm{CR}_{\mathrm{wo} \text {-media }}$ data alone. One way forward would be to expand the data set used in determining phylogenetic relationships to include databases containing data on element concentrations in reptiles, but without the corresponding media data required to calculate $\mathrm{CR}_{\text {wo-media }}$ 
values. Such databases were excluded from the current $\mathrm{CR}_{\text {wo-media }}$ compilation for reptiles presented by Wood et al. [4], but the Residual Maximum Likelihood (REML) fitting of a mixed model regression used by Willey [39], enables $\mathrm{CR}_{\text {wo-media }}$ and concentration data to be combined within the analysis. With some additional literature review work, it may therefore be possible to establish at least broad phylogenetic relationships for reptiles.

\subsection{Allometric relationships}

Another method for filling data gaps on radionuclide transfer to reptiles is the use of allometric (or biological scaling) relationships, such as the kinetic-allometric approach presented by Higley et al. [41], for which the major uptake and elimination pathways must be quantified to achieve a mechanistic prediction of radionuclide transfer. The allometric approach is based on the observation that many physiological parameters relate to body mass via a power function [41], commonly scaling to quarter powers of the mass [42]. Allometric relationships generally take the form:

$$
Y=a M^{b}
$$

where $Y$ is the physiological parameter to be estimated, $M$ is the organism mass and $a$ and $b$ are constants derived from measured data.

By estimating the uptake and elimination rates of radionuclides based on allometric scaling relationships for parameters such as food ingestion rate, life span and radionuclide biological halflife, it is possible to obtain radionuclide transfer predictions that are in good agreement with measured data [43]. Although initially developed for mammals (e.g. [44]), the applicability of biological scaling to poikilotherms and ectotherms has also been demonstrated [45, 46]. For example, Reichle et al. [45] derived the following equation to predict the biological half-life $\left(\mathrm{T}_{1 / 2 b}\right)$ of radiocaesium in poikilothermic vertebrates at $20^{\circ} \mathrm{C}$ :

$$
Y_{C s}=38.02 M^{0.1390}
$$

where $Y_{C s}$ is the biological half-life of radiocaesium and other terms have been defined previously. The value of the $b$ constant in the above equation is noteworthy because it isn't a quartile value. For endothermic animals, $T_{1 / 2 b}$ generally scales to quarter power values (e.g. [47]). This suggests that allometric radionuclide transfer relationships for reptiles may differ from those for birds and mammals, two groups which have previously been used to estimate transfer data for reptiles in the absence of reptile-specific data [48].

An advantage of an allometric approach is that it provides a method for predicting transfer to species across a broad mass range [41], which for reptiles extends from $10^{-4} \mathrm{~kg}$ for species such as the Sphaerodactylus ariasae (dwarf gecko) [49] to $10^{3} \mathrm{~kg}$ for species such as the Dermochelys coriacea (leatherback turtle) [50]. Therefore, developing reptile-specific allometric relationships may provide an alternative to the use of CRs when predicting radionuclide transfer to reptiles. Again, this is an area for further work.

\section{CONCLUSIONS}

Despite the importance of reptiles in many ecosystems and the need to consider this organism group within biota dose assessments, the data available to predict radionuclide transfer to reptiles remain limited. Non-lethal sampling techniques, phylogenetic relationships and allometric relationships are three approaches which have the potential to increase the availability of parameters to predict radionuclide transfer to reptiles. In the long term, developing and refining non-lethal sampling techniques is likely to be the most desirable option because this will allow the derivation of $\mathrm{CR}_{\mathrm{wo} \text {-media }}$ data based on empirical measurements and enable direct measurements of tissue concentrations in reptiles at sites requiring assessment. However, this will require extensive research and development 
to develop robust relationships between non-lethally sampled tissues and whole body activity concentrations. In the interim, pursuing the derivation of phylogenetic and allometric relationships may be a more pragmatic approach. However, it is recognised that this would be facilitated by further empirical measurements to expand current data sets.

\section{Acknowledgments}

This work has been facilitated by interactions within the IAEA EMRAS II Working Group on Wildlife Transfer.

\section{References}

[1] Beresford, N.A., Barnett, C.L., Beaugelin-Seiller, K., Brown, J.E., Cheng, J-J., Copplestone, D., Gaschak, S., Hingston, J.L., Horyna, J., Hosseini, A., Howard, B.J., Kamboj, S., Kryshev, A., Nedveckaite, T., Olyslaegers, G., Sazykina, T., Smith, J.T., Telleria, D., Vives i Batlle, J., Yankovich, T.L., Heling, R., Wood, M.D., Yu, C., Radioprotection 44 (2009) 565-570.

[2] Wood, M.D., Beresford, N.A., Barnett, C.L., Copplestone, D., Leah, R.T., J Environ Radioact 100 (2009) 1034-1052.

[3] IAEA (International Atomic Energy Agency) (2011) Handbook of parameter values for the prediction of radionuclide transfer in Wildlife. IAEA, Vienna (Draft in press)

[4] Wood, M.D., Beresford, N.A., Semenov, D.V., Yankovich, T.L., Copplestone, D., Radiat Environ Biophys 49 (2010) 509-530.

[5] Wood, M.D., Marshall, W.A., Beresford, N.A., Jones, S.R., Howard, B.J., Copplestone, D., Leah, R.T., J Environ Radioact 99 (2008) 1484-1495.

[6] Hopkins, W.A., Roe, J.H., Snodgrass, J.W., Jackson, B.P., Kling, D.E., Rowe, C.L., Congdon, J.D., Environ Pollut, 115 (2001), 1-7.

[7] Brisbin, I.L., "Radiocesium levels in a population of American alligators: a model for the study of environmental contaminants in free-living crocodilians", In Proceedings of the 8th working meeting of the Crocodile Specialist Group of the Species Survival Committee of the International Union for Conservation of Nature and Natural resources. (IUCN, Quito, 1989).

[8] Pough, F.H., Andrews, R.M., Cadle, J.E., Crump, M.L., Savitzky, A.H., Wells, K.D., Herpetology 3rd edn (Pearson Prentice Hall, New Jersey, 2004).

[9] Markich, S.J., Jeffree, R.A., Harch, B.D., Sci Total Environ 287 (2002) 83-95.

[10] Twining, J.R., Markich, S.J., Prince, K.E., Jeffree, R.A., Environ Sci \& Technol 33 (1999) 43964400.

[11] Jeffree, R.A., Markich, S.J., Tucker, A.D., Sci Total Environ 336 (2005) 71-80.

[12] Day, R.D., Christopher, S.J., Becker, P.R., Whitaker, D.W., Environ Sci Tech 39 (2005) 437-446.

[13] Schneider, L., Belger, L., Burger, J., Vogt, R.C., Sci Total Environ 407 (2009) 1048-1054.

[14] Takagi Y, Matsuda S, Imai S, Ohmori Y, Masuda T, Vinson JA, Mehra MC, Puri BK, Kaniewski A., Bull Environ Contam Toxicol 41 (1988) 690-695.

[15] Seltzer, M.D., Berry, K.H., Sci Tot Environ 339 (2005) 253-265.

[16] Burger, J, Campbell, K.R., Murray, S., Campbell, T.S., Gaines, K.F., Jeitner, C., Shukla, T., Burke, S., Gochfeld, M. Sci Total Environ 373 (2007) 556-563.

[17] Kaur, S., Sci Total Environ, 77 (1988) 289-290.

[18] Burger, J., Campbell, K.R., Campbell, T.S., Shukla, T., Jeitner, C., Gochfeld, M., Arch Environ Contam Toxicol 49 (2005) 232-238.

[19] Burger, J., Arch Environ Contam Toxicol 22 (1992) 209-213.

[20] Jones, D.E., Holladay, S.D., Ecotox Environ Safety 64 (2006) 221-225.

[21] Mann, R.M., Serra, E.A., Soares, A., Environ Toxicol Chem 25 (2006) 3199-3203.

[22] Burger, J., Gochfeld, M., Rooney, A.A., Orlando, E.F., Woodward, A.R., Guillette, L.J., Arch Environ Contam Toxicol 38 (2000) 501-508. 
[23] Burger, J., J Toxicol Environ Health 41 (1994) 207-220.

[24] Godley, B.J., Thompson, D.R., Furness, R.W. Mar Pollut Bull 38 (1999) 497-502.

[25] Xu, Q.H., Fang, S.G., Wang, Z.W., Wang, Z.P. Arch Environ Contam Toxicol 50 (2006) 580-586.

[26] Burger, J., Environ Monit Assess 77 (2002) 255-263.

[27] Guirlet, E., Das, K., Girondot, M., Aquatic Toxicol 88 (2008) 267-276.

[28] Sakai, H., Ichihashi, H., Suganuma, H., Tatsukawa, R., Mar Pollut Bull 30 (1995) 347-353.

[29] Lam, J.C.W., Tanabe, S., Chan, S.K.F., Lam, M.H.W., Martin, M., Lam, P.K.S., Environ Pollut 144 (2006) 790-801.

[30] Clark, D.R., Bickham, J.W., Baker, D.L., Cowman, D.F., Environ Toxicol Chem 19 (2000) 22592265.

[31] Brisbin, I.L., Staton, M.A., Pinder, J.E., Geiger, R.A., Copeia (1974) 501-506.

[32] LaportaFerreira, I.L., Santos, S.M.A., Santoro, M.L., Saiki, M., Vasconcelos, M.B.A., J Nat Toxins 6 (1997) 103-110.

[33] Bjarnason, J.B., Fox, J.W., Pharmacol Therapeut 62 (1994) 325-372.

[34] Xu, X.L., Liu, X.H., Zhang, L.Y., Chen, J.X., Liu, W.Q., Liu, Q.L., Protein Journal 25 (2006) 423-430.

[35] Xu, X.L., Zhang, L.Y., Shen, D.K., Wu, H., Peng, L.L., Li, J.H., J Biol Inorg Chem 14 (2009) 559-571.

[36] Lance, V.A., Cort, T., Masuoka, J., Lawson, R., Saltman, P., J Zool 235 (1995) 577-585.

[37] Cuadrado, M., Molina-Prescott, I., Flores, L., Veterinary Journal 166 (2003) 93-97.

[38] Gochfeld, M., Burger, J. Biol Trace Elem Res 12 (1987) 389-399.

[39] Willey, N.J., Radiat Environ Biophys 49 (2010) 613-623

[40] Jeffree, R.A., Oberhansli, F., Teyssie, J-L., Sci Total Environ 408 (2010) 3200-3210

[41] Higley, K.A., Domotor, S.L., Antonio, E.J., J Environ Radioact 66 (2003) 61-74.

[42] West, G.B., Brown, J.H., Enquist, B.J., "The origin of universal scaling laws in biology", J.H. Brown \& G.B. West, Scaling Biology (Oxford University Press, New York, 2000) pp 87-112

[43] Beresford, N.A., Broadley, M.R., Howard, B.J., Barnett, C.L., White, P.J., J Radiol Prot 24 (2004) 89-103

[44] Adolph, E.F., Science 109 (1949) 579-585

[45] Bennett, A.F., Dawson, W.R., "Metabolism”, C. Gans \& F.H. Pough, Biology of the Reptilia. (Academic Press, New York, 1976).

[46] Reichle, D.E., Dunaway, P.B., Nelson, D.J., Nucl Saf 11 (1970) 43-55.

[47] Coughtrey, P.J., Thorne, M.C., Radionuclide distribution and transport in terrestrial ecosystems. A critical review of data Vol. 1. (A.A. Balkema, Rotterdam, 1983).

[48] Beresford, N.A., Barnett, C.L., Howard, B.J., Scott, W.A., Brown, J.E., Copplestone, D., J Environ Radioact 99 (2008) 1393-1407.

[49] Hedges, S.B., Thomas, R., Caribb J Sci 37(2001) 168-173.

[50] Arnold, N., A field guide to the reptiles and amphibians of Britain and Europe. (Collins, London, 2004). 